\title{
Prey preference of the stone crab Platyxanthus crenulatus (Decapoda: Platyxanthidae) in laboratory conditions
}

\author{
María Victoria Laitano*, Nahuel Emiliano Farías and Maximiliano Cledón
}

(MVL) IIMyC, CONICET - Universidad Nacional de Mar del Plata, Deán Funes 3350, Mar del Plata. E-mail: vlaitano@mdp.edu.ar.

(NEF) Laboratorio de invertebrados, Departamento de Biología, Universidad Nacional de Mar del Plata, Deán Funes 3350, Mar del Plata. E-mail: nefarias@mdp.edu.ar

(MC) IIMyC, CONICET - Universidad Nacional de Mar del Plata, Deán Funes 3350, Mar del Plata. E-mail: mcledon@mdp.edu.ar.

*Corresponding author

\begin{abstract}
The preference for a particular type of prey implies an active behavioral choice of the predator. The present work deals with the prey preference of the large stone crab Platyxanthus crenulatus among similar sized gastropods and bivalves of different substrates using a recent proposed methodology based on a two-stage approach. In laboratory, crabs received different mollusk species separately to determine the consumption in number of each species when choice was not possible. Further, crabs were offered the same mollusc species but together to record differences of specific consumption when choice was possible. Results were then compared to assess prey preferences. Platyxanthus crenulatus is able to effectively attack and consume the majority of the sympatric mollusk species, although preferred the dominant species Brachidontes rodriguezii over the others. Such preference seems to be driven by shell shape and thickness which may be a common pattern in prey preference among large stone crab species.
\end{abstract}

Key words: bivalves, gastropods, South-western Atlantic, trophic behavior, xanthids

\section{INTRODUCTION}

The distribution and abundance of a consumer can be explained largely by the distribution and abundance of the resources it uses and vice versa (Begon et al., 1996). However, most predators do not consume prey items in proportion to their abundance, but select particular sizes and/or types of prey (Micheli, 1995), generating non random associations.

Such associations are often explained as a direct consequence of the preference for a particular prey (Underwood et al., 2004). Nevertheless the concept of preference implies the existence of active behavioral choice (Singer, 2000). Furthermore, consumption patterns are influenced by intrinsic features of prey and its interaction with the predator (Underwood et al., 2004) rather than predator choice along.

In this sense, many different definitions and experimental designs have been suggested and used to test preference (Johnson, 1980; Newman et al., 2010; Saunders et al., 2012), but there is certainly a consensus that it is essential to clarify the used definition before starting to work (Taplin, 2007). A relatively new point of view has been developed by some authors (Singer, 2000; Underwood et al., 2004). Singer (2000) stated that preference depends exclusively on predator and implies 
some predator own behavior. Underwood and Clarke (2005) include this point in the definition: "When an animal is confronted with choices of resource, preference would be a behavior that results in use not predicted from behavior when no choice is available" and this concept was the approach used in the present study.

Large crabs, particularly those which prey on mollusks, were successfully used as model to test general hypothesis on prey selection and optimal foraging (e.g. Cancer sp. - Yamada and Boulding, 1998; Carcinus sp.- Smallegange et al., 2008; Menippe sp.Aronhime and Brown, 2009). Platyxanthus crenulatus A. Milne-Edwards, 1879, is one of four edible crab species belonging to the South American family Platyxanthidae Guinot, 1977 ( $\mathrm{Ng}$ et al., 2008). The species is restricted to south western Atlantic coasts, inhabiting the intertidal and shallow subtidal waters of north of Patagonia (Boschi, 1964). Adults are more common in subtidal rocky reefs, where are the most conspicuous invertebrate predators. In Mar del Plata these crabs are often seen feeding on small mussels and sporadically on other invertebrates such as ascidians and polychaetes. However, their claws show strong positive allometry in both sexes, with marked heteroquely and laterality (i.e. dimorphism between chelae and the tendency to present them in a particular side of the body); both traits often associated to durophagous habits (Seed and Hughes, 1995). The general morphology of the species is the classical of the large stone crabs, i.e. conspicuous animals with robust bodies that reach large sizes and strong claws. Such crabs are usually highlevel predators (Gerhart and Bert, 2008) and dominant over other competitor crab species (Brown et al., 2005).

Mollusk species differ in life history traits, morphology and shell thickness among others. Moreover, they often inhabit different substrates and consequently present distinctive defenses, such as burying and/or clustering behaviors, which may decrease encounter rates or increase handling times. In turn, the different shell morphologies can affect selection patterns (Bourdeau and O'Connor, 2003; Addison, 2009). Whilst the prey size preference has received much attention (see
Juanes, 1992; Smallegange and van der Meer, 2003), works dealing with preference among different prey species are contrastingly rare (Ebersole and Kennedy, 1995; Mascaró and Seed, 2001) probably due to the complexity of such systems, in which different factors interact at the same time.

In this work we investigate the prey preference of $P$. crenulatus among different mollusk species. For this, laboratory experiments were carried out (1) to determine prey preference among preys of differing shell shape and (2) to test for differences in the pattern of preference in different habitats.

\section{Material And Methods}

Species and sampling

In December 2008 and January 2009, 80 individuals of Platyxanthus crenulatus were manually collected from the rocky shore adjacent to Nágera Biological Coastal Station, Mar del Plata (38 $\left.09^{\prime} \mathrm{S} / 57^{\circ} 38^{\prime} \mathrm{W}\right)$ and by diving from Mar del Plata port and La Restinga reef. Simultaneously, the most abundant mollusks cohabiting with these crabs (Scelzo et al., 2002; Farías, 2011) were collected from hard and soft bottoms. Hard bottom species were the gastropod Tegula patagonica (d'Orbigny, 1835), the mussels Brachidontes rodriguezii (d'Orbigny, 1842) and Mytilus edulis Linnaeus, 1758, which were collected by hand from the intertidal area of Waikiki beach, Mar del Plata (38 $\left.04^{\prime} S / 57^{\circ} 32^{\prime} \mathrm{W}\right)$. The soft bottom species were the clam Mesodesma mactroides Reeve, 1854 which was collected manually at Punta Mogotes beach, Mar del Plata (38 $\left.03^{\circ} \mathrm{S} / 57^{\circ} 32^{\prime} \mathrm{W}\right)$ and the gastropod Buccinanops monilifer (Kiener, 1834) which was collected in shallow waters off that beach using a dredge $(100 \mathrm{~cm}$ opening, $30 \mathrm{~cm}$ height and $1 \mathrm{~cm}$ mesh size) at $5 \mathrm{~m}$ depth.

Only crabs $\geq 50 \mathrm{~mm}$ in carapace width (adults) with undamaged chelae and in the late inter-moult stage were used in the experiments to avoid any interference of the life cycle or moult stages in the results. The commonest prey sizes found in the field varied between 25 to $30 \mathrm{~mm}$ in $T$. patagonica, 20 to $30 \mathrm{~mm}$ in $B$. rodriguezii, 35 to $45 \mathrm{~mm}$ in $M$. edulis platensis, 25 to $40 \mathrm{~mm}$ in $B$. monilifer and 35 to 45 $\mathrm{mm}$ of $M$. mactroides. Animals were kept in 
5001 tanks with flow-through seawater. Prior to experiments, crabs were starved during 72 hours to standardize hunger levels.

\section{Experimental design and statistical analysis}

Experiments were carried out under 12L:12D light conditions in 1001 close system sea water aquaria and containing a $10 \mathrm{~cm}$ sand bottom to ensure that $M$. mactroides could reach its usual life depth (Cledón and Nuñez, 2010). To provide substrate to preys and refuge to crabs, rocks were placed at the center of each tank simulating the rocky outcrops found in the natural habitat. Water was continuously oxygenated through air injection pumps and replaced each 48 hours.

The experimental design and the statistical analysis were performed according to Underwood and Clarke (2005) based on the definition of preference exposed in the previous section. The experiments consisted in two stages as follows: in the first one, individual crabs were presented with a single prey species; in stage 2, individuals were offered all prey types simultaneously (Fig. 1).

\section{Stage 1: Consumption without choice}

In this stage we first determined if $P$. crenulatus is able to consume the offered prey species. Further, for the prey species they can consume, we registered the number of consumed individuals of each species when choice is not available. It consisted on five experiments (E1-E5), one per each prey species (Fig. 1). Each crab was offered three individuals of the same prey species and allowed to feed for 48 hours. Ten replicates of each experiment were done. Preys were introduced at first and

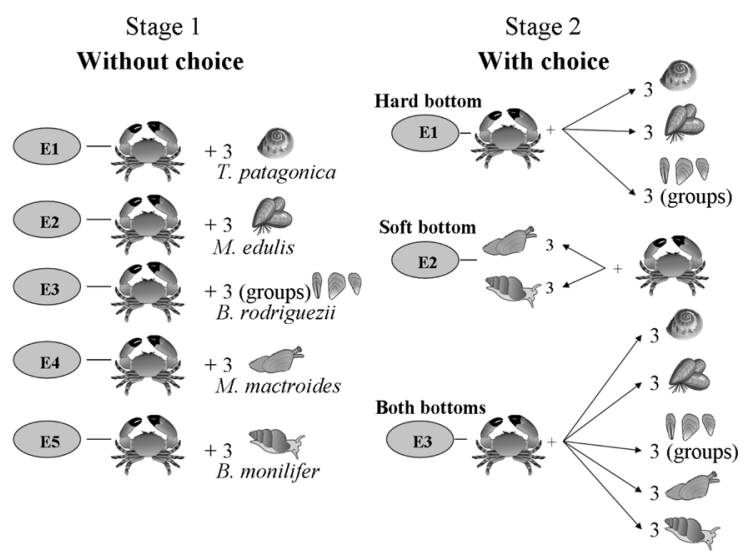

Figure 1. Feeding experiments design. E1-E5: Experiment 1 - Experiment 5. when they were on their life position, crabs were placed in the tanks. Due to the small size of $B$. rodriguezii, it was placed in groups of a similar volume to one individual of the other prey species. Each group was considered as a unique individual in statistical analysis.

\section{Stage 2: Consumption with choice}

In the stage 2, crabs were allowed to choose among the prey species. It consisted on three experiments (E1-E3) where each crab was offered: three individuals (or groups) of each hard bottom species (E1), three individuals of each soft bottom species (E2) and three individuals of all prey items (E3), simultaneously (Fig. 1). Ten replicates of each experiment were done and after 48 hours the number of individuals consumed of each prey species when choice was possible was registered. All trails were carried out within a six-week period, with different individuals of P. crenulatus and different individuals of preys in order to avoid autocorrelation of data.

\section{Preference Test}

Some difference in the consumed proportions between stages 1 and 2 for at least one prey species would be indicating preference by $P$. crenulatus, since its feeding behavior would differ according to the possibility of choice or not. Thus, the consumed numbers of each prey species were compared with the numbers expected on the basis of no preference, using $\chi 2$ test. The expected numbers were obtained through Maximum Likelihood equations derived from Underwood and Clarke (2005; Section 2.5 and Appendix A.4) while the observed values were those obtained from experiments of stage 2 . Once we proved preference, we could determine a rank of most preferred preys by simply ordering the specific $\chi 2$ values, the higher the $\chi^{2}$ the higher the preference for it.

\section{Predation marks}

At the end of each experiment, we recorded and photographed the marks left by the crab on the shell of consumed animals, in an attempt to determine if there are specific patterns on prey manipulation that might be related either to the different substrates or to specific shell features. 


\section{RESULTS}

All the offered species were consumed by Platyxanthus crenulatus except Tegula patagonica (Table 1), whose shells actually did not show any sign of attack. In all experiments, there were differences among expected and observed values (all $\mathrm{p}<0.01$; Table 1 ) indicating that at each trial, preys were eaten through an active election based in preference instead of attacking preys randomly.

In "hard bottom experiments" (E1), the preferred prey species was Brachidontes rodriguezii. In "soft bottom experiments" (E2), the preferred prey species was Mesodesma mactroides. When crabs were offered all prey species simultaneously (E3) the most preferred was $B$. rodriguezii and followed by $M$. mactroides (Table 2).

\section{Predation marks}

Among the studied bivalves there were two types of shell remains. Mytilus edulis appeared almost intact but with the anterior part of the valve broken. In turn, valves of $M$. mactroides and $B$. rodriguezii appeared totally destroyed and in all cases the soft tissue completely consumed. In contrast, the shells of the gastropod Buccinanops monilifer were found with characteristic predation marks in the lip and soft tissues were not fully consumed (Fig. 2).

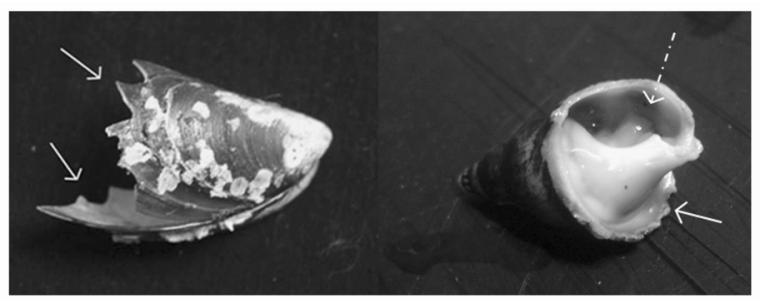

Figure 2. Predation marks of $P$. crenulatus observed after experiments in Mytilus edulis (left) and Buccinanops monilifer (rigth) shells. The dotted arrow shows remnants of soft tissues.

\section{Discussion}

Our experiments first confirmed that the stone crab Platyxanthus crenulatus is able to consume the majority of the sympatric mollusk species, whether they inhabit hard or soft bottoms. Secondly, we have demonstrated the preference of $P$. crenulatus for the most abundant of all, the mussel Brachidontes rodriguezii, and probed that these crabs use particular handling techniques regarding the different species consumed.

Table 1. Consumed individuals of each prey species by ten P. crenulatus in $48 \mathrm{~h}$. At stage I preys species were offered separately; at stage II (with hard bottom species) T. patagonica, M. edulis platensis and B. rodriguezii were offered together; at stage II (with soft bottom species) $M$. mactroides and B. monilifer were offered together and at stage II (both bottoms species) all prey items were offered at the same time. Observed values were obtained directly from experiments. Expected values of stages II were obtained from the fitting of stage I data. Three Chi square tests evaluate the difference between those values.

\begin{tabular}{|c|c|c|c|c|c|c|c|c|c|c|c|c|}
\hline \multicolumn{13}{|c|}{ Number of prey individuals consumed } \\
\hline & \multicolumn{2}{|c|}{$\begin{array}{c}\text { Tegula } \\
\text { patagonica }\end{array}$} & \multicolumn{2}{|c|}{$\begin{array}{l}\text { Mytilus } \\
\text { edulis }\end{array}$} & \multicolumn{2}{|c|}{$\begin{array}{c}\text { Brachidontes } \\
\text { rodriguezzi }\end{array}$} & \multicolumn{2}{|c|}{$\begin{array}{c}\text { Mesodesma } \\
\text { mactroides }\end{array}$} & \multicolumn{2}{|c|}{$\begin{array}{c}\text { Buccinanops } \\
\text { monilifer }\end{array}$} & \multirow[t]{2}{*}{$\begin{array}{c}\text { Chi } \\
\text { square }\end{array}$} & \multirow[t]{2}{*}{ p-value } \\
\hline & Obs & Exp & Obs & Exp & Obs & Exp & Obs & Exp & Obs & Exp & & \\
\hline Stage I & 0 & & 10 & & 16 & & 10 & & 11 & & & \\
\hline $\begin{array}{l}\text { Stage II } \\
\text { (hard bottom) }\end{array}$ & 0 & 0 & 7 & 2.75 & 16 & 4.75 & & & & & 33 & $<0.01$ \\
\hline $\begin{array}{l}\text { Stage II } \\
\text { (soft bottom) }\end{array}$ & & & & & & & 9 & 3.78 & 6 & 3.71 & 9 & $<0.01$ \\
\hline $\begin{array}{l}\text { Stage II } \\
\text { (both bottoms) }\end{array}$ & 0 & 0 & 4 & 1 & 13 & 2 & 6 & 1 & 6 & 1 & 102 & $<0.01$ \\
\hline
\end{tabular}

Table 2. Differences between consumption of P. crenulatus at stage II (when choice among species of hard bottom, soft bottom or both was possible) and the expected consumption (Obs.-Esp. $)^{2} /$ Esp. The last one was calculated from consumption when choice was not possible (stage I). a: Prey species preferred by $P$. crenulatus at the corresponding experiment.

\begin{tabular}{|c|c|c|c|c|c|}
\hline & Tegula patagonica & Brachidontes rodriguezii & Mytilus edulis platensis & Buccinanops monilifer & Mesodesma mactroides \\
\hline Hard bottom & 0 & $37.26^{\mathrm{a}}$ & 3.25 & & \\
\hline Soft bottom & & & & 0.12 & $18.75^{\mathrm{a}}$ \\
\hline $\begin{array}{l}\text { Hard and soft } \\
\text { bottom }\end{array}$ & 0 & $85.33^{\mathrm{a}}$ & 4 & 8 & 25 \\
\hline
\end{tabular}


Although using different methodologies, previous works dealing with prey selection in other large stone crab species, had found similar results as ours. Morales and Antezana (1983) observed that Homalaspis plana $(\mathrm{H}$. Milne Edwards, 1834) preferred the mussel Semirnytilus algosus (Gould, 1850) over the snail Tegula atra (Lesson, 1830), although the energy content and the manipulation time were estimated the same for the two species. However, the probability of successfully breaking the shells was higher for S. algosus than for $T$. atra, which would explain the preference. In turn, Cancer novaezealandiae (Jacquinot, 1853) also selected the mussel Mytilus edulis over gastropod preys, which again is related with prey profitability (Energy content/manipulation time) (Creswell and McLay, 1990). Moreover, soft bottoms crabs, although generally classified as opportunistic and generalised predators (Gordon and Wear, 1999), have shown similar preferences. Callinectes sapidus (Rathbun, 1896), exhibited a strong relation between their preference among three bivalves species and the profitability of each one, choosing that of the thinnest shell (Ebersole and Kennedy, 1995). Carcinus maenas (Linnaeus, 1758) choose mussels over oysters; in that case the authors related this preference to differences in profitability and shell volume (Dare et al., 1983; Mascaró and Seed, 2001).

As in the above cited studies, in the present work purple stone crabs preferred bivalves with the thinnest shells over thick shelled bivalves and those over gastropods, and did not attack the snail Tegula patagonica, even when no other prey species were available. Moreover, the remains of attacked preys during our experiments showed clear differences in the way in which gastropod and bivalve species are manipulated for consumption. This could be seen as a prey selection pattern in large stone crabs of many species. And probably this pattern could be also found in other shell breaking crabs, although to asseverate this, more studies in these species are needed.

On the other hand, it is expected to found differences in encounter rates and the way in which the preys are caught if comparing different substrates, thus affecting consumption rates. P. crenulatus inhabit caves and crevices of hard rocky bottoms (Boschi, 1964); therefore they encounter hard bottom preys much more frequently than soft bottom ones. However, these crabs did not prefer preys of any particular substrate (at E3 of stage 2 crabs prefer Mesodesma mactroides at second place instead of Mytilus edulis). Thus, the prey substrate is not a factor driving the $P$. crenulatus consumption of the prey species used here.

Lastly, predation affects directly community structure (Virnstein, 1977; Menge et al., 1985). Due to $B$. rodriguezii is the dominant species at the study area (Penchaszadeh, 2004) we could expect that the P. crenulatus preference has important indirect effects on community diversity and structure however this is not the case. We assume this because these mussels reach a great abundance of about 81.262 ind. $/ \mathrm{m}^{2}$ (Penchaszadeh, 1973 ) and the predation rate of $P$. crenulatus in laboratory condition was 6 to 8 ind/day. Thus, the preferred prey population would endure the predation pressure of this crab species.

Under the light of these findings, $P$ crenulatus selects its preys following the same pattern than other congeners stone crabs species which might be explained by foraging elections based on preys shell shape and thickness. In this context when similar sized preys are encountered, the crab attacks those with the softer shell, even when hard shelled preys are easily accessible. Further studies should be addressed to explore more in deep these prey features that drive $P$. crenulatus preference.

ACKNOWLEDGMENTS - The present work was partially supported by the project EXA 453/09 of Universidad Nacional de Mar del Plata and PICT 2007-01398 of the National Agency of Scientific and Technological Promotion. We are especially grateful to Fundación Mar del Plata Aquarium to the access to aquaria facilities, to Emiliano Ocampo and Jesús Nuńez for critically reading the manuscript and to Miguel A. Perez and Michael Long, RN, BSN, MHA, Ph .D. for English corrections. Finally we would like to thank to Anabella Zavatteri and Nicolás Chiaradia for their help on laboratory conditioning and sampling and two anonymous reviewers for helpful comments that greatly improved de MS. 


\section{REFERENCES}

Addison, B. 2009. Shell Traits of a Marine Mussel Mediate Predation Selectivity by Crabs and Sea Stars. Journal of Shellfish Research, 28(2): 299-303.

Aronhime, B.R. and Brown, K.M. 2009. The roles of profit and claw strength in determining mussel size selection by crabs. Journal of Experimental Marine Biology and Ecology, 379: 28-33.

Begon M.; Harper, J.L. and Townsend, C.R. 1996. Ecology: individuals, populations and communities. Blackwell Sci., Oxford. $2^{\text {da }}$. edición inglesa: (1990), Ed. Omega, Barcelona. 1068 p.

Bourdeau, P.E. and O'connor, N.J. 2003. Predation by the nonindigenous asian shore crab Hemigrapsus sanguineus on macroalgae and mollusks. Northeastern naturalist, 10(3): 319- 334 .

Boschi, E.E. 1964. Los Crustáceos Decápodos Brachyura del Litoral Bonaerense (República Argentina). Boletín Institucional de Biología Marina 6, 100 p.

Brown, K.M.; Keenan, S.F. and Banks, P.D. 2005. Dominance hierarchies in xanthid crabs: roles in resource-holding potential and field distributions. Marine Ecology Progress Series, 291: 189-196.

Cledón, M. and Nuñez, J.D. 2010. Siphon nipping facilitates lethal predation in the clam Mesodesma mactroides (Reeve, 1854) (Molluska: Bivalva). Marine Biology, 157: 737-745.

Creswell, P.D. and McLay, C.L. 1990. Handling times, prey size and species selection by Cancer novaezelandiae feeding on molluskan prey. Journal of Experimental Marine Biology and Ecology, 140: 13-28.

Dare, P.J.; Davies, G. and Edwards, D.B. 1983. Predation on juvenile pacific oysters Crassostrea gigas and mussels Mytilus edulis by shore crab Carcinus maenas. Fisheries Research Technical Report MAFF 73, 15 p.

Ebersole, E.L. and Kennedy, V.S. 1995. Prey preferences of blue crabs Callinectes sapidus feeding on three bivalve species. Marine Ecology Progress Series, 118:167-177.

Farias, N.E. 2011. Habitat and life history of the purple stone crab Platyxanthus crenulatus (Milne Edwards 1897) (Brachyura: Platyxanthidae). PhD Thesis. Departamento de Biología. Universidad Nacional de Mar del Plata. 145 pp.

Gerhart, S.D. and Bert, T.M. 2008. Life-history aspects of stone crabs (Genus Menippe): size at maturity, growth, and age. Journal of Crustacean Biology, 28: 252-261.

Gordon, D.P. and Wear, R.G. 1999. A new ctenostome bryozoan ectosymbiotic with terminal moult paddle crabs (Portunidae) in New Zealand. New Zealand Journal of Zoology, 26(4): 373-380.

Johnson, D.H. 1980. The comparison of usage and availability measurements for evaluating resource preference. Ecology, 61(1): 65-71.

Juanes, F. 1992. Why do decapod crustaceans prefer smallsized molluskan prey? Marine Ecology Progress Series, 87: 239-249.

Mascaró, M. and Seed, R. 2001. Choice of prey size and species in Carcinus maenas (L.) feeding on four bivalves of contrasting shell morphology. Hidrobiología, 449: 159170.

Menge, B.A.; Lubchenco, J. and Ashkenas, L.R. 1985. Diversity, heterogeneity and consumer pressure in a tropical rocky intertidal community. Oecologia, 65: 394405.
Micheli, F. 1995. Behavioral plasticity in prey-size selectivity of the blue crab Callinectes sapidus feeding on bivalve prey. Journal of Animal Ecology, 64(1): 63-74.

Morales, C. and Antezana, T. 1983. Diet selection of the Chilean stone crab Homalaspis plana. Marine Biology, 77: 79- 83.

Newman, S.P.; Handy, R.D. and Gruber, S.H. 2010. Diet and prey preference of juvenile lemon sharks Negaprion brevirostris. Marine Ecology Progress Series, 398: 221-234.

Ng, P.K.L.; Guinot, D. and Davie P. 2008. Systema Brachyororum: Part I. An annotated checklist of extant brachyuran crabs of the world. The Raffles Bulletin of Zoology, 17: 1-286.

Palmer, A.1985. Adaptive value of shell variation in Thais lamellosa: effect of thick shells on vulnerability to and preference by crabs. Veliger, 27(4): 349-356.

Penchaszadeh, P.E. 1973. Ecología de la comunidad del Mejillín (Brachidontes rodriguezii D'Orb) en el mediolitoral rocoso de Mar del Plata (Argentina): el proceso de recolonización. Physis, 32(84): 51-64.

Penchaszadeh, P.E. 2004. Caracoles, almejas y mejillones. p. 253-270. In: Boschi E.E. and Cousseau M.B. (eds.) La vida entre mareas: vegetales y animales de las costas de Mar del Plata, Argentina. Publicaciones Especiales INIDEP, Mar del Plata, Argentina.

Saunders, M.I.; Thompson, P.A.; Jeffs, A.G.; Säwström, C.; Sachlikidis, N.; Beckley L.E. and Waite, A.M. 2012. Fussy Feeders: phyllosoma larvae of the Western rocklobster (Panulirus cygnus) demonstrate prey preference. PLoS ONE 7(5): e36580. doi:10.1371/journal.pone.0036580.

Scelzo, M.A.; Martinez Arca, J. and Lucero, N.M. 2002. Densidad, diversidad y biomasa de la macrofauna componente de los fondos de pesca "Camarón-langostino", frente a Mar del Plata, Argentina (1998-1999). Revista de Investigación y Desarrollo Pesquero, 15: 43-65.

Seed, R. and Hughes, R.N. 1995. Criteria for prey sizeselection in molluskivorous crabs with contrasting claw morphologies. Journal of Experimental Marine Biology and Ecology, 193: 177-195.

Singer, M.C. 2000. Reducing ambiguity in describing plantinsect interactions: "preference", "acceptability" and "electivity”. Ecology Letters, 3: 159-162.

Smallegange, I.M. and van der Meer, J. 2003. Why do shore crabs not prefer the most profitable mussels? Journal of Animal Ecology, 72: 599-607.

Smallegange, I.M.; Hidding, B.; Eppenga, J.M.A. and van der Meer, J. 2008. Optimal foraging and risk of claw damage: How flexible are shore crabs in their prey size selectivity? Journal of Experimental Marine Biology and Ecology, 367: 157-163.

Taplin, R.H. 2007. Experimental design and analysis to investigate predator preferences for prey. Journal of Experimental Marine Biology and Ecology, 344: 116-122.

Underwood, A.J.; Chapman, M.G. and Crowe, T.P. 2004. Identifying and understanding ecological preferences for habitat or prey. Journal of Experimental Marine Biology and Ecology, 300: 161-187. 
Underwood, A.J. and Clarke, K.R. 2005. Solving some statistical problems in analyses of experiments on choices of food and on associations with habitat. Journal of Experimental Marine Biology and Ecology, 318: 227-237.

Virnstein, R.W. 1977. The importance of predation by crabs and fishes on benthic infauna in Chesapeake Bay. Ecology, 58: 1199-1217.

Yamada S.B. and Boulding, E.G. 1998. Claw morphology, prey size selection and foraging efficiency in generalist and specialist shell-breaking crabs. Journal of Experimental Marine Biology and Ecology, 220: 191-211. 